\title{
Implementation of Solar Technologies in the Development of Rural, Remote and Sub urban Communities
}

\author{
N. M. Khattab, H. Soliman, M. Metias, I. El-Seesy, E. Mettawee, E. El-Shenawy, M. Hassan \\ Solar Energy Department, National Research Center, Giza, Egypt, 12622
}

\begin{abstract}
This case study describes a model household in which a number of simple solar technologies are utilized to provide for the daily household needs of electricity, clean water, cooling and heating. The model was named "Solar Home". A "Solar Home" is primarily suited to rural, remote and sub urban low income communities that suffer from lack of access to grid electricity and clean quality water. However, with the increased demand on energy in urban communities connected to grid electricity, the "Solar Home" can serve as a practical solution in the near future. The case study presents the results of the studies carried out on a pilot scale Solar Home project built in the Solar Energy Department, NRC, Egypt. The solar system designs used in the pilot Solar Home project are practical, easy to install and maintain, as well as inexpensive. The systems would serve two purposes; domestic services and some income generating activities. The case study discusses the performance of the selected solar systems under actual climatic conditions of Egypt, their costs. The case study will detail recommendations for the optimum implementation of the suggested systems and the needed training to use those systems. Finally the case study will list some of the lessons learned and the challenges faced during implementation and operation.
\end{abstract}

Keywords: Solar Home, Domestic Solar Systems, Generating Activities systems, Costs

\section{Introduction}

Solar Home studies for sustainable development of rural, remote and sub urban areas has been conducted in a number of countries in Africa, Asia and South America. Those studies have been used to inform the case study with current trends, best practices and challenges met. To that effect, the review of renewable energy for sustainable development in South Africa, Egypt, Nigeria and Mali revealed its socioeconomic effect on the local communities[1]. The case studied in Cuba showed how a combination of technology and policy that targeted the improvement of livelihoods in rural areas [2]. The evolution of the rural household energy consumption structure in northern China from 1996 to 2005 studies highlighted the countermeasures to overcome the obstacles involved in the sustainable development of rural household energy [3]. The productivity of solar home systems in isolated areas in French Guiana helped in the better understanding of the attitudes, expectations, and relationship of the users towards the solar home system.[4]. The gradual shift of Bangladesh towards exploring renewable energy resources as a driving force for rural development and the demonstrations of implemented projects offered valuable lessons in the importance of the careful forward planning of renewable energy in providing far-

${ }^{*}$ Corresponding author. Tel.: +202 33335946

Fax: +202 33370931; E-mail: nag khb@yahoo.com

(C) 2010 International Association for Sharing Knowledge and Sustainability

DOI: $10.5383 /$ ijtee.03.02.001 reaching economic, environmental, and social benefits to people living in remote rural areas[5]. systems Additionally, the effect of solar photovoltaic-based home electrification system for rural development was studied. Lessons learned from these experiences showed that PV can play a useful role for rural development and rural electrification purposes [6,7], [8-10]. The change in livelihood as a result of the access to electric services in Zambia has been studies. Zambia has been operating 100 solar home systems since the year 2000.and a survey showed that though light hours did not increase, yet the quality of light was improved, enabling activities such as domestic work at night and studying for longer hours [11]. The incorporation of solar energy in Botswana has contributed to almost all aspects of development in rural areas. Solar systems include solar water heating for domestic and commercial uses, solar desalination to provide potable water, passive solar buildings, photovoltaic devices for lighting, refrigeration, communication [12].

In Egypt, the government has exerted tremendous efforts in developing low income communities, rural and remote areas that suffer from lack of access to grid electricity and clean quality water. The main challenge facing those efforts is the rapid population growth and the inability of current energy and water resources to catch up with this rapid increase. An effective approach adopted to meet the challenge of scarce energy and water resources is the utilization of renewable energy sources and especially solar energy to produce the 
needed energy for developing those communities. The adopted approach has been motivated mainly by Egypt's location and what this location offers in terms of solar energy abundance. Egypt lies in a high solar insulation band and is endowed with abundant solar energy and good weather conditions most of the year, besides it posses long sea shores and underground brackish water supply. This case study was inspired by the many efforts to develop low income communities, rural and remote areas that suffers from lack of access to energy, and clean water. The study targets low-income communities in suburban and rural areas. It also has a strong component of raising awareness regarding renewable energy and its benefits. In order to fulfill the developmental component, the technologies applied in this case study do not only meet energy and water needs; but they are also geared to particular economic and socio cultural conditions. A well engineered solar energy system that is cost effective and highly reliable can improve the quality of life in those areas. The economic constraints can be met if these systems are fundamentally well designed, use appropriate technology and make use of effective load control techniques. In this case study the match between efficient technology engineering, high reliability, and simple and effective operation as seen from the user, is investigated. Economic analyses are performed for different energy systems. In this study, PV installation is minimized to reduce costs as the PV is expensive compared to thermal devices. So, their usages are minimized as much as possible to only lighting and refrigerator. The study implemented solar designs that are based on the work and studies carried out by the solar energy staff to optimize and cost effective solar technologies. In this study, designs, operation, performance and costs are carried out for the selected systems. Biogas are also presented. The systems used in this study are simple in design, manufactured using simple techniques and available materials in the local market. The systems were manufactured in a small work shop attached to the Solar Department.

\section{Solar Systems Under Investigations}

The solar systems investigated and tested in the solar home project are chosen according their simplicity, economical costs as well as good performance. The systems are of two types, first; domestic types and second; for some income generating activities residential activities. Solar System Investigated (Design, Performance under actual conditions and Costs) have been discussed in this project.

\subsection{Domestic Solar systems}

\subsubsection{Water Desalination}

The lack of potable water poses a big problem in remote, arid and some costal areas of Egypt. Egypt has long sea shores and underground water which, is usually brackish and cannot be used as it is for drinking purposes. As Egypt lies in high solar insolation band, the vast solar potential can be exploited to convert saline water to potable water. The most economical and easy way to accomplish this objective is using solar desalination as in residential remote and arid areas, the desalination needs not exceed a few cubic meters per day. Solar stills are used to produce fresh water by directly utilizing sunshine. These stills represent the best technical solution to supply families in Egypt with fresh water without depending on high-tech and skills

The selected L type solar still designed in our Department [13, 14] is modified to increase energy absorbed by its basin without increasing the basin area. This can be achieved by using a corrugated absorber as a still basin. The corrugated surface should be selected such that the angle of incidence of solar radiation is minimum, and consequently, the input solar energy is maximum. Another advantage of corrugation is that the heat transfer area between water and still basin increases. The theoretical analysis carried out to select the corrugation angle and the orientation for maximum energy input to the still is in $[13,14]$. A planer reflector is used to increase the energy input to the still without increasing its area. The corrugation of the absorber as a still basin may be oriented with its tilted to East- west or to North-south directions. The energy input is calculated for the two cases to show the most suitable orientation for maximum possible daily energy input to the still $[13,14]$. In this study, $\psi$ is taken to be equal $50^{\circ}$ to avoid sun spot to the corrugated basin ( $\psi$ is the angle of corrugation measured with horizontal). The modified single basin solar still of area $(100 \times 50 \mathrm{~m})$ shown in Fig.1 was designed and tested under actual climatic conditions in Cairo. It is made of galvanized iron and insulated from sides and bottom. The reflector is made from stainless steel. The inclination of glass cover was chosen to be $30^{\circ}$ (latitude of Cairo) for both summer and winter.

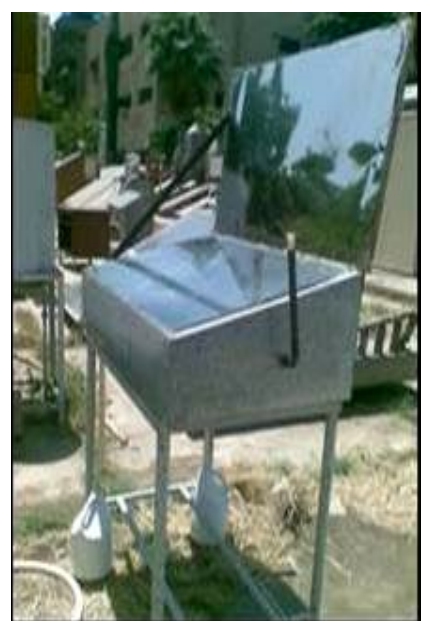

Fig. 1 Modified single $L$ basin solar still

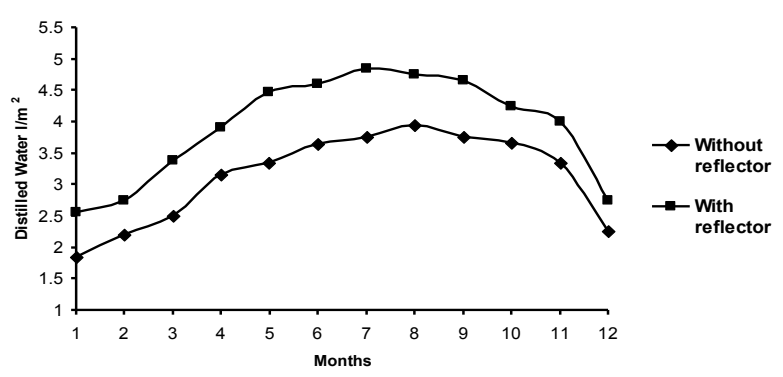

Fig. 2 Daily productivity of the still all year round with and without reflector

Figure 2 shows the water productivity all round year with and without using reflector. It is found that, the use of reflector 
with still resulted in an increase in the daily water productivity by an average value equal $38 \%$. The average productivity reaches $3.751 / \mathrm{m}^{2}$ day all round the year due to using reflector. This unit of area $0.5 \mathrm{~m}^{2}$ costs $100 \$$ with stainless steel reflector and costs $65 \$$ with aluminum sticker reflector. It has a life time of 15 years.

\subsubsection{Water disinfection (Batch type)}

While there are many methods for water purification, there are only a few that are practical in remote rural areas. Chlorination is practical for small communities but is difficult to implement at the point of use. Pasteurization and boiling are effective ways for purification but they are not eliminate any chemical contaminants in which some of which cause severe bad health effect. An inexpensive process called SODIS was developed. This technology uses the effect of solar UV radiation for the inactivation and destruction of microorganisms in drinking water. The technology is as simple as filling a plastic bottle with water and exposing it to solar radiation for a determined time. Other advantages of this technology is the low cost (it can use recycled bottles) and the avoidance of chemicals, such as chlorine. SODIS is ideal for rural areas because it requires only small volumes of water(less than 2 liters /bottle). Polyethylene terephtalate (know as PET) is a material used in the manufacturing of plastic bottles and contains stabilizers that protect the plastic against the UV effects. Due to its low weight, transmissivity of UV-A radiation and chemical stability, it is preferred as the material for SODIS treatment.

Litter et al. [15] have developed a technique that combines both SODIS and photocatalyst methods in order to use their advantages. The performance of the PET bottles coated with a $\mathrm{TiO} 2$ was studied in this work. These bottles can be used for solar water disinfection because $\mathrm{TiO} 2$ combines the action of solar disinfection (SODIS) and advanced oxidation process improving the effectiveness of these technologies [15].

The performed tests consisted in studying the effect of disinfecting water by direct exposure to sunlight during the whole day with solar concentrators, in plastic bottles of commercial beverages Fig.3. The three types of bottles used were transparent, partially painted black (one half of the bottle, along the longitudinal axis), and partially painted black from outside and partially painted with $\mathrm{TiO} 2$ from inside.

Through experiments, it was found that titanium dioxide thin film could be deposited on the surface of PET bottles by creating a suspension with distilled water, titanium dioxide and some binding agent. Sodium acetate was found to be the best agent in phoocatalytic testing, inexpensive, has a desirable safety rating, and can be manufactured in remote area with baking soda and vinegar.

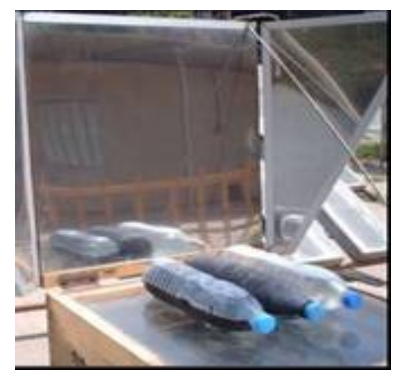

Fig.3 The three types of water disinfection bottles

The three bottles were exposed to the sun light for half an hour before usage to guarantee their sterilization before conducting the experiment, and then they were filled with water sample contaminated with bacteria.

The bacteriological examination was conducted on water samples to examine three different parameters UV, heat, and photocatalytic oxidation with $\mathrm{np}-\mathrm{TiO}_{2}$. These parameters include the total bacterial counts $/ \mathrm{ml}$. To evaluate the effectiveness of the three systems of treating the infected water, Table (1) shows the data if the bacteriological analysis and the effect if the solar energy (UV and heat) and the effect of photocatalytic oxidation by $\mathrm{np}-\mathrm{TiO}_{2}$ thin film removing bacteria

Table (1) The effect of the solar energy and the photocatalytic oxidation by $\mathrm{np}-\mathrm{TiO}_{2}$ thin film on the total bacterial counts $(\mathrm{CFU} / \mathrm{ml})$ :

From table (1) it is obvious that the treatment of np- $\mathrm{TiO}_{2}$ to the

\begin{tabular}{|c|c|c|c|c|}
\hline Sample & $\begin{array}{c}\text { Untreated } \\
\text { bottle } \\
\text { (CFU/ml) }\end{array}$ & $\begin{array}{c}\text { Half } \\
\text { black } \\
\text { bottle } \\
\text { (CFU/ml) }\end{array}$ & $\begin{array}{c}\text { Half black- } \\
\text { TiO } \text { thin film } \\
\text { treated bottle } \\
\text { (CFU/ml) }\end{array}$ & $\begin{array}{c}\text { Sample } \\
\text { Temp } \\
\left({ }^{\circ} \mathbf{C}\right)\end{array}$ \\
\hline Starting & 44 & 44 & 44 & 25 \\
\hline After 1 hr & 37 & 18 & 16 & 37 \\
\hline $\begin{array}{c}\text { After 2 } \\
\text { hrs }\end{array}$ & 13 & 12 & 2 & 45 \\
\hline $\begin{array}{c}\text { After 3 } \\
\text { hrs }\end{array}$ & 12 & 1 & 1 & 51 \\
\hline $\begin{array}{c}\text { Efficiency of } \\
\text { Bacterial } \\
\text { Removal(\%) }\end{array}$ & 72.7 & 97.7 & 97.7 & \\
\cline { 1 - 3 } & &
\end{tabular}

PET bottle was superior to the other systems in this study, due to the effectiveness of the photocatalytic oxidation process occurred by the $\mathrm{TiO}_{2}$ nano particles exposed to UV light.

As we see, the costs of this method is very low as we need already used plastic bottles. The only cost is the cost of the black paint and $\mathrm{TiO} 2$ (amount to $2 \$$ for ten 2 liters bottles). then total cost of the unit for 10 bottles will be $(9$ \$) with reflector using aluminum stickers and if we use stainless steel reflector the unit costs $40 \$$.

\subsubsection{Solar water heaters}

In poor communities in Egypt, water is normally heated using agricultural residues which produces smoke and is generally unsafe. In more well- off communities, electric or gas water heaters are used, but there may be shortages of gas cylinders, or electricity costs may be high. Egypt is well endowed with solar energy, so solar water heating is a viable option. Although solar water heaters are now becoming popular in Egypt, yet, is still out of reach to many poor. Simple solar collector and storage system which is made from local material and simple design and could be made in small work shop to reduce its cost was built. As a result, it is possible to get hot water from the collectors at a fraction of the cost that would to be paid, if bought a commercially made or imported one.

The solar water heater system designed Fig.4, is of thermosyphone type consists of a solar collector and storage tank. The collector which $\left(1 \mathrm{~m}^{2}\right.$ area) made from copper tubes with aluminum fins and two risers, insulated from the bottom by insulation thickness $5 \mathrm{~cm}$ and covered by glass $(3 \mathrm{~mm}$ thickness). The storage tank is of 801 capacity. 


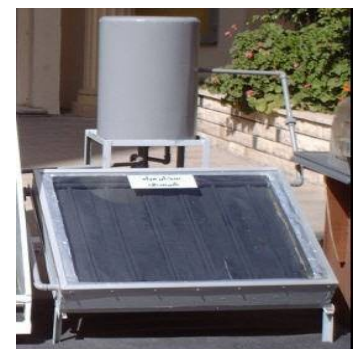

Fig. 4 Thermosyphone solar water heater

The use of solar energy to heat water for household use reduces or eliminates the need to use agricultural waste or other traditional fuels to heat the water in rural areas, thereby reducing greenhouse gas emissions. Fig 5 shows the performance of the solar water heater unit with 1 meter water pass under actual climatic conditions of Cairo in summer season. Its performance is studied since starting of heating 80 liter of cold water with drainage of $25 \%$ of its content daily. Maximum temperature reached about $60{ }^{\circ} \mathrm{C}$ and water temperature rise during day is $10-12{ }^{\circ} \mathrm{C}$ and temperature above ambient range from $25-30{ }^{\circ} \mathrm{C}$. The system under consideration costs 270 \$_ and has a life time is 15 years.

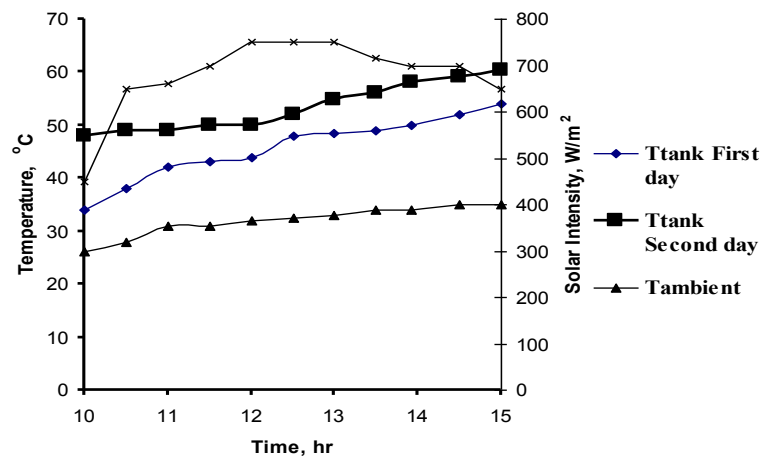

Fig. 5 Average water temperature inside the storage tank for two consecutive days

In this study, two types of solar cookers are constructed and tested in summer season of Egypt. In those cookers, two types of plane reflectors arrangements are designed to heat the cookers. Figure 6 shows Type A of the suggested reflectors arrangement. It consists of three parts, the middle one (facing south) has the same size as the receiver aperture area $(0.55 \times 0.55 \mathrm{~m})$, with surface azimuth angle equal to zero and has an angle $\mathrm{B}$ with horizontal. The other two parts (wings) are in the form of a triangle with $(0.55 \times 0.55 \mathrm{~m})$ sides. They make an angle of $135^{\circ}$ to the middle part with the surface azimuth angle of $45^{\circ}$. They are used to collect sun rays in early morning from east and late afternoon from west. The middle reflector tilt angle B is chosen according the work of [16], so as to receive maximum energy input at noon time throughout the year.

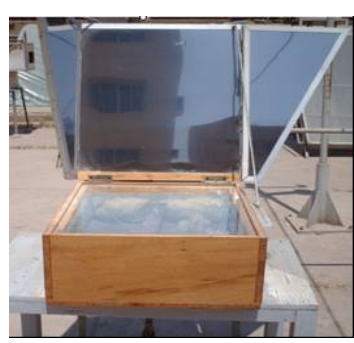

Fig. 6 Solar cooker Type
The second plane reflectors arrangement Type B is shown in Fig.7. It consists of two plane reflectors, one facing south with angle B1 with horizontal and the other is facing north with an angle B2 with horizontal. The two reflectors have the same receiver aperture area $(0.55 \times 0.55 \mathrm{~m})$. The tilt angles of both reflectors are optimized by [17] to receive maximum energy during noon time through out the year. The angles of inclinations of both arrangements to achieve maximum energy at noon time all year round are shown in Table 2. The cookers are made of wooden box, insulated from both sides and bottom, covered with double glass layers.. The reflectors are made of wooden plate and covered with stainless steel plate (for cheap cooker, aluminum stickers could be used instead of the stainless steel).

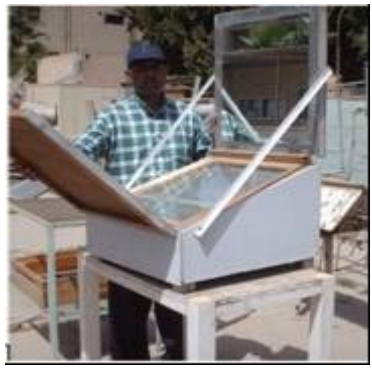

Fig. 7 Solar cooker Type B

Table 2 Angles of inclinations of both arrangements to achieve maximum energy at noon time all year round

\begin{tabular}{|c||c|cc|}
\hline & Type A & \multicolumn{2}{|c|}{ Type B } \\
\hline \hline Months & $\mathbf{B}^{\mathbf{0}}$ & $\mathbf{B}_{\mathbf{1}}{ }^{\mathbf{2}}$ & $\mathbf{B}_{\mathbf{2}}{ }^{\mathbf{2}}$ \\
\hline \hline Jan. & 94 & 100 & 23 \\
\hline \hline Feb & 89 & 94 & 28 \\
\hline Mar. & 80 & 87 & 34 \\
\hline \hline Apr. & 73 & 78 & 42 \\
\hline May & 68 & 71 & 50 \\
\hline June & 66 & 69 & 52 \\
\hline Jul. & 68 & 69 & 50 \\
\hline \hline Aug. & 74 & 75 & 43 \\
\hline \hline Sep. & 80 & 85 & 36 \\
\hline \hline Oct. & 92 & 92 & 28 \\
\hline Nov. & 89 & 97 & 22 \\
\hline \hline Dec. & 96 & 101 & 20 \\
\hline
\end{tabular}

The cookers are tested in the Solar Energy Department under climatic condition in June. Temperature of both the air inside the cookers as well as temperature of 2 liter of water during heating until boiling and boiling time are shown in Fig 8 . From this figure, cooker type A attained higher temperature and water boiled more faster

Type A costs $90 \$$ with stainless steel reflector and $50 \$$ with aluminum sticker. Type B costs $95 \$$ with stainless steel reflector and $55 \$$ with aluminum sticker. The life time is 15 years 


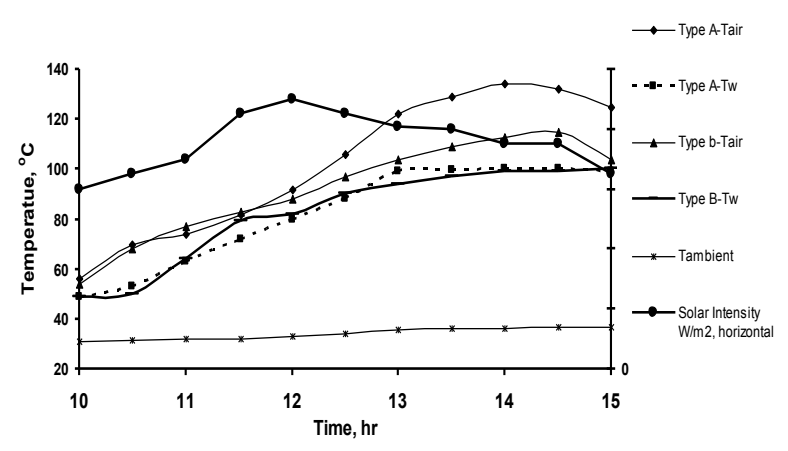

Fig. 8 Temperature of the air inside the cookers and water temperature against the time until boiling

\subsubsection{Solar Cooling (Sky radiation)}

The majority of air conditioning systems currently in operation are all air systems in which the recirculated air is used to remove excess heat from the building. This air is recooled by passive or positive cooling systems. Passive cooling although not highly effective, yet it is more simpler and of less costs.

In the tested unit we used cold water to cool circulating air inside the solar home. We utilize sky radiation to cool water during night and used this water during day time to cool the solar home. The study aims to investigate experimentally the natural nocturnal cooling of stagnant water by night sky radiation in thermally insulated tank where the heat loss by radiation to the sky is only from the tank upper surface at night by sky radiation

To size this system, a room of $1 \mathrm{~m} 3$ volume was cooled by different volumes of water cooled by sky radiation (minimum cooled water reaches during night about $24{ }^{\circ} \mathrm{C}$ during June Month). Water from the cooled tank is circulated inside a heat exchanger by using small pump (30 Watt) and air passed through the heat exchanger and drawn into the room by using small fan 10 Watt). The tank volume of 25 liter is found the minimum water volume more suitable for cooling the room( temperature was kept constant around $27{ }^{\circ} \mathrm{C}$ for six hours). Figure 9 shows the system. Fig. 10 shows the variation of storage tank temperature during nocturnal cooling at night and cooling water temperature during day time as well as the room air temperature during day time. From this figure, water depression during night is about $6{ }^{\circ} \mathrm{C}$ and reaches a minimum to $24{ }^{\circ} \mathrm{C}$ The cooling water temperature during day time range

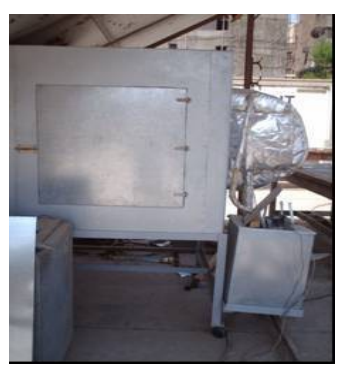

Fig. 9 Sky radiation cooling of $1 \mathrm{~m}^{3}$ room

between $25-26{ }^{\circ} \mathrm{C}$ while the room air temperature is about 27 ${ }^{\circ} \mathrm{C}$ in the day time for about 6 hours. The small cooling unit(storage tank, fan, heat exchanger and pump) costs $50 \$$ to cool $1 \mathrm{~m}^{3}$. The total power needed is $40 \mathrm{~W}$ for running 6 hours daily during day time and $50 \%$ access for storage.

The costs of PV will be calculated later

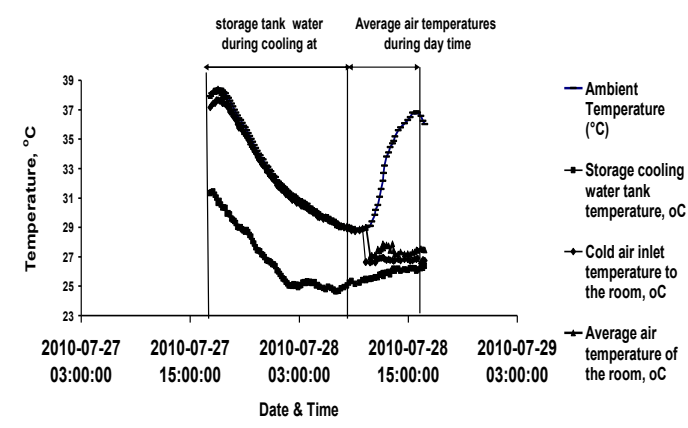

Fig 10 Cooling temperature inside the tank during night and room temperature during day time

heating, chicken farm heating and agricultural drying. The unglazed solar air heating panels have become the preferred method of heating air using solar energy in cold climates where temperature rise required is not high. Monitoring work of the solar perforated unglazed wall heating systems has revealed interesting results and that the unglazed panels outperform the traditional glazed solar panels and at lower capital costs. The perforated air heater is shown in Fig 11. The width and length of the absorber plat were $0.6 \mathrm{~m}$ and $1.8 \mathrm{~m}$, respectively. It is perforated by $3 \mathrm{~mm}$ circular holes. The distance between the centers of the holes in the two dimensions is $1 \mathrm{~cm}$. The perforated plate is painted with black paint. The air is withdrawn from upper to lower surface by using small fan (15 Watt)

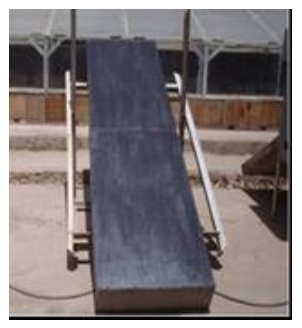

Fig 11 Unglazed perforated solar air heater

The temperature rise across the unglazed solar air heater is from $4-6^{\circ} \mathrm{C}$ during day time which make it suitable for heating houses in cold climate and could be used for chicken farm heating during day time directly without using storage system. The unit costs $70 \$$

\subsubsection{Refrigerators}

The application of solar power for food preservation purposes is a field with high potential specially in rural areas with abundant solar energy and where there is lack of electrical energy supply. Alternative refrigeration systems other than compression systems are required. Such systems are presented and discussed in this study. It includes photovoltaic (PV) powered absorption system and (PV) powered thermoelectric system.

The possibility of using PV to power small cooling aquaammonia absorption Fig.12 unit is investigated. The absorption cooling unit is of commercially produced Electrolux type (Three-fluid continuous performance system). This particular absorption refrigerator type is a three-way fridge with the option of three heat sources (electricity, battery or LPG gas). It is characterized by its simplicity as it has no mechanical pumps or compressor to circulate the refrigerant within the 
system but only proper leveling is required to provide correct refrigerant flow in the gravity-feed system. In this paper, solar system is designed to drive a refrigerator 125 Liter volume. The refrigerator is driven by special DC electric heater $(80$ Watt) designed in the Solar Department and gets its electric supply from the PV units From the experimental results of the system, two PV arrays of 80 Watt and solar battery are required for driving the refrigerator under different weather conditions. The evaporator and cabinet temperatures during cooling is shown in Fig 13. The cooling refrigerator price costs $270 \$$. The costs of PV will be calculated later

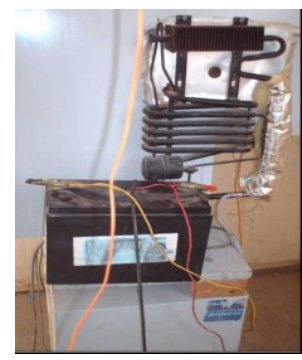

Fig. 12 Solar Absorption Refrigerator

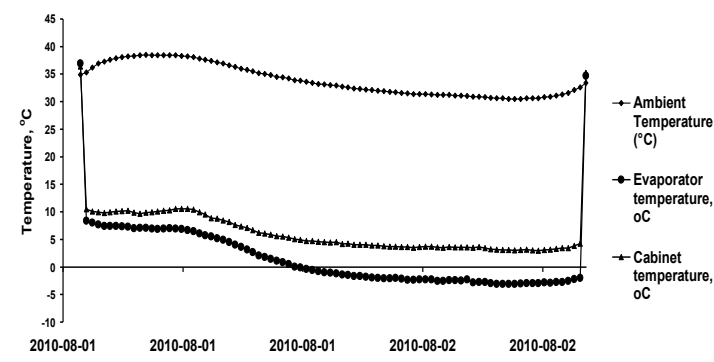

Fig.13 Temperature of the evaporator and cabinet of the refrigerator

Thermoelectric refrigerator is also driven by PV solar cells. A system composes of PV cells and lead batteries as storage medium could be used. An optimal choice of the number of cells and batteries could result in an energy inventory and management of the overall power system, with high reliability, low maintenance costs, long life time, high charging efficiency and high voltage stability .

Experimental investigations on solar PV driven thermoelectric Refrigerator shown in Fig 14 (15 Liter Volume) has been conducted. Storage battery is used to provide electric energy in the night and in cloudy or rainy days. Experiment results demonstrate that the unit can maintain the temperature in the refrigerator at $5-10{ }^{\circ} \mathrm{C}$. It needs a 40 watt power. It is expected that the refrigerator would be potential for cold storage of vaccine, foodstuffs and drink in remote area.

The unit price is $90 \$, \mathrm{PV}$ costs will be calculated later

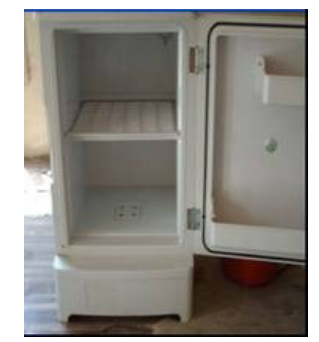

Fig. 14 Solar thermoelectric refrigerator

\subsubsection{Lighting and $P V$}

Photovoltaic solar cells could be used as an alternative power supply for many solar applications. In this project we determine the costs of stand-alone, household-sized solar PV for application in remote and rural areas of Egypt. This system shown in Fig 15, aims to supply the electric energy to rural zone family home for two days without any sun shine and has the following loads: 4 DC lamps of 15 Watt each, DC Refrigerator, Pumps, fans and 4 AC outputs for small loads such as radio, mobile charge, etc.

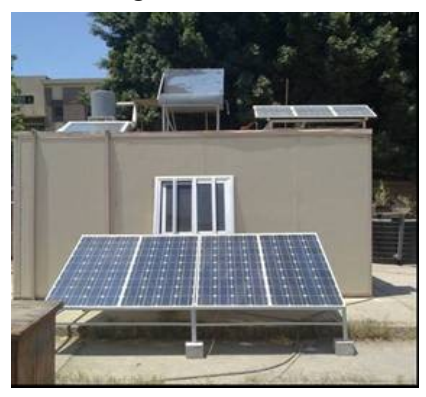

Fig. 15 Solar home and PV systems

\subsection{Some income generating Activities}

\subsubsection{Ice Makers}

solid adsorption refrigeration system is one of the most promising technologies to produce ice, especially in non electrified areas, and where solar energy is abundant. The main objective of this project is to develop and test simple type of solar adsorption ice makers for different applications specially fish preservation that would be appropriate to costal areas. It can help fishermen to preserve cached fish in remote area. This would reflect positively on income and standard of living of those fishermen. The collector-adsorber, Fig 16 is multitubular with an opaque black radiation-absorbing surface, covered with two layers of glass and its base is thermally insulated. The solar radiation hits the glass of the tubes by means of plane reflector.

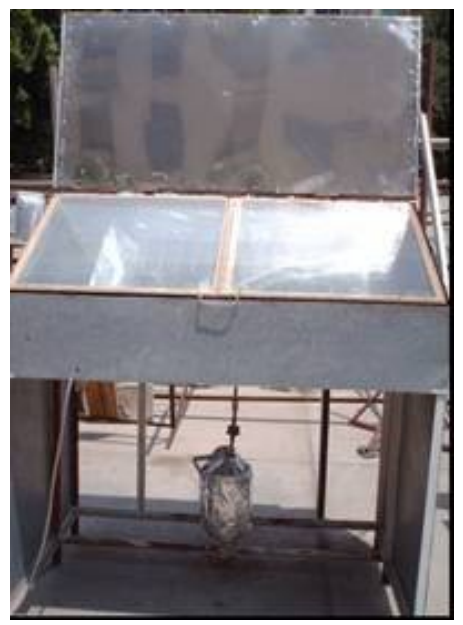

Fig 16 Ice maker unit 
Heating of the adsorber in June lasted about 7 hours with an average solar intensity on horizontal equal $700-750 \mathrm{Watt} / \mathrm{m} 2$. The adsorber temperature during heating ranging between 100 $110{ }^{\circ} \mathrm{C}$. Cooling results for water carried during night for 3 , 4.5 and $61 / \mathrm{m}^{2}$ is shown in Fig 17. Maximum/Minimum ambient temperature is $36 / 24{ }^{\circ} \mathrm{C}$. It is found that this system can produce $4.5 \mathrm{~kg}$ of ice/ $\mathrm{m}^{2}$ daily. This unit costs $270 \$$ to produce $4.5 \mathrm{~kg}$ of ice $/ \mathrm{m}^{2}$ daily

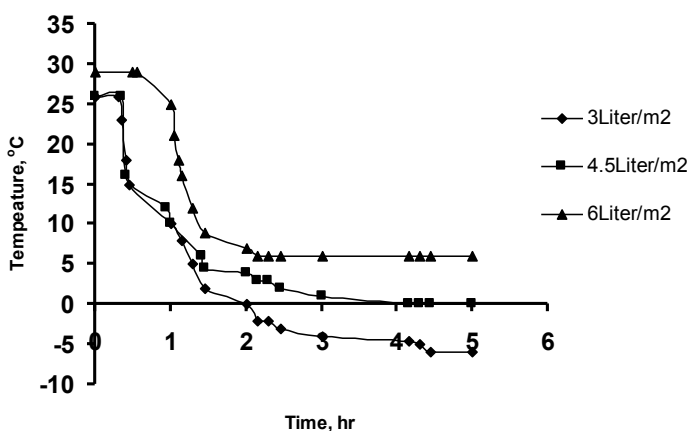

Fig. 17 Ice production per day

\subsubsection{Solar Dryers}

Two groups of solar-energy dryers can be identified, viz passive or natural-circulation solar-energy dryers and active or forced-convection solar-energy dryers (often referred to as hybrid solar dryers). The appropriateness of each design type for application is determined by rural farmers in developing countries, the capacity of drying materials and the weather condition of the place. Fig. 18 shows a natural family size solar

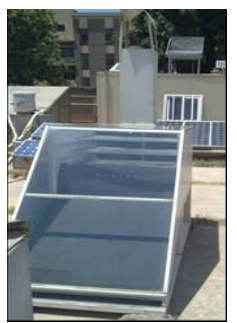

\section{Fig. 18 Natural circulation family solar dryer}

composed of one unit (solar collector and drying chamber) built and tested. It is made of wood and has a small storage system from pebble bed at its base. It could be used in drying about $5-7 \mathrm{~kg}$ of wet materials. So it could be used for families in the open roof or a open area as it is portable and has a small size. Temperature of the drying room during drying $5 \mathrm{~kg}$ of menthol is shown in Fig 19 Also, solar radiation and ambient temperature. This unit costs $160 \$$

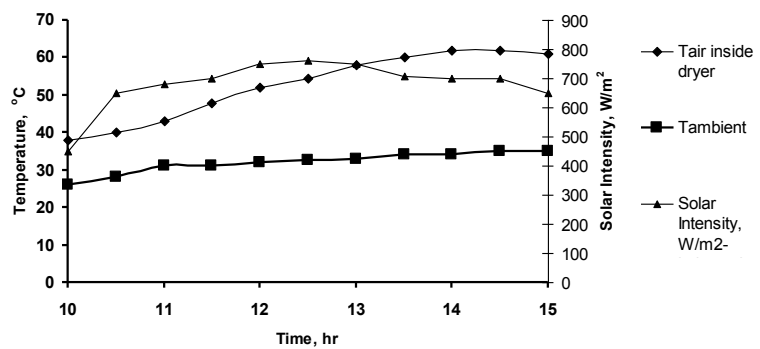

Fig. 19 Temperature inside the dryer during drying Menthol

\subsection{Solar Assisting System}

Biogas technology (BGT) is one of the appropriate technologies which could be used successfully in solar assisting systems

\subsubsection{Compact Biogas System}

Biogas is produced through a process of anaerobic digestion of organic materials. The system is made from cut down polyethelyne tanks and consists of a and a free floating gas holder. The Compact Biogas System [18], Fig 20 fabricated by H. Farag(private sector), does not use cow dung to produce gas, it uses kitchen food waste, which is 400 times more efficient. . Using kitchen food waste as feed stock allows for the system to compact and fit in almost any location. All that is needed to install a compact biogas system is direct sunlight and 1.5 meters square of space. The system is also clean, ordourless, safe and easy to use.

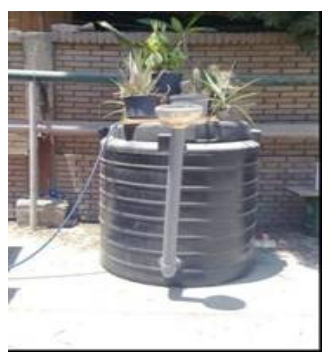

Fig. 20 Compact Bio gas unit

ARTI Africa and its commercial partner, Joint Environmental Techniques (JET) has installed Compact Biogas Systems in homes. Other important benefits of the compact biogas system are: The system reduces the dependence on LPG, Kerosene, Electricity and Charcoal, The system can be scaled up in size and in numbers to meet the requirement, Relatively Low Investment and space required, Quick and easy installation and relocation, Produces an Organic Fertilizer as a By-product. The Bio Gas unit shown in Fig 19 is used in driving the absorption refrigerator and used for cooking This unit costs $160 \$$

\section{Project Results and Recommendations}

The tested desalination unit gives about 3.75 liter/ $\mathrm{m} 2$ per day. As each person needs at least 4 liters/day, so we need an area of about $1.25 \mathrm{~m} 2$ from this type of still for each person. So the total cost per person will be $240 \$$. The life time is about 15 years. The treatment of np- $\mathrm{TiO}_{2}$ to the PET bottle was superior to the other systems in this study, due to the effectiveness of the photocatalytic oxidation process occurred by the $\mathrm{TiO}_{2}$ nano particles exposed to UV light. Time of purification need about three hours.

The water disinfection method used is very cheap specially if use aluminum sticker on a thin flat plate wood as reflector. Good purification could be also achieved if the duration time of exposing the bottles to the sun without reflector is doubled [15]. It is a simple method for water disinfection for rural and remote area. The solar water heating system is sufficient to supply two persons with hot water in the range of $50-60{ }^{\circ} \mathrm{C}$. To increase outlet temperature, collector of length $1.5 \mathrm{~m}$ is more suitable which means that collector costs increase by $50 \%$ while tank cost is still the same. The two cookers can cook two pans (each $20 \mathrm{~cm}$ Diameter) and each contain 1 liter. The price of the two cookers could be decreased if we use aluminum 
sticker instead of stainless reflector. The life time is from 10-12 years. The first study indicated that cooling by using night radiation is feasible mainly during summer season. So, a larger room ( $20 \mathrm{~m} 3$ volume) will need a water pump of 100 Watt and water tank of 500 liters water and a fan of 60 Watt. (Total 160 Watt for six hours daily).

A simple low cost solar air heater could be used to heat houses directly from solar energy during day time without storage. The Bio gas unit could be used for three hours daily for cooking or driving the absorption refrigerators. The PV units required of about $0.5 \mathrm{KW}$ with 4 batteries and converter system which totally costs $3500 \$$ for the operation of the implemented systems

\section{Conclusion}

Different solar systems are constructed and tested to be used in rural, remote and sub urban areas. The systems would serve two purposes; domestic services and some income generating activities.

The case study discusses the performance of the selected solar systems under actual climatic conditions of Egypt and their costs. The case study will detail recommendations for the optimum implementation of the suggested systems. The solar home tested presents a sustainable developmental model, likely to be replicated in rural, remote and sub urban areas with under privileged populations

\section{References}

[1] I.M. Bugaje, Renewable energy for sustainable development in Africa: a review,Renewable and Sustainable Energy Reviews, Volume 10, Issue 6, 2006, 603-612 http.dx.doi.org/10.1016/j.rser.2004.11.002

[2] Judith A. Cherni, Yohan Hill, Energy and policy providing for sustainable rural livelihoods in remote locations - The case of Cuba, Geoforum, Volume 40 Issue 4, July 2009, Pages 645-654.

[3] Zhongren Zhou, Wenliang Wu, Qun Chen, Shufeng Chen, Study on sustainable development of rural household energy in northern China, Renewable and Sustainable Energy Reviews, Volume 12, Issue 8, October 2008, Pages 2227-2239 http.dx.doi.org/10.1016/j.rser.2007.03.007

[4] L. Linguet, I. Hidair, A detailed analysis of the productivity of solar home system in an Amazonian environment, Renewable and Sustainable Energy Reviews, Volume 14, Issue 2, February 2010, Pages 745753. http.dx.doi.org/10.1016/i.rser.2009.06.015

[5] Md. Alam Hossain Mondal, Linda M. Kamp, Nevelina I. Pachova, Drivers, barriers, and strategies for implementation of renewable energy technologies in rural areas in Bangladesh-An innovation system analysis, Energy Policy, Volume 38, Issue 8, 2010, 46264634. http.dx.doi.org/10.1016/j.enpol.2010.04.018
[6] F. van der Vleuten, N. Stam, R. van der Plas, Putting solar home system programmes into perspective: What lessons are relevant?, Energy Policy, Volume 35, Issue 3, March 2007, Pages 1439-1451. http.dx.doi.org/10.1016/i.enpol.2006.04.001

[7] O. Adeoti, B. A. Oyewole, T. D. Adegboyega, Solar photovoltaic-based home electrification system for rural development in Nigeria: domestic load assessment, Renewable Energy, Volume 24, Issue 1, September 2001, Pages 155-161. http.dx.doi.org/10.1016/S09601481(00)00188-9

[8] Stefan C. W. Krauter, Development of an integrated solar home system, Solar Energy Materials and Solar Cells, Volume 82, Issues 1-2, 2004, 119-130

[9] B.M. Taele, K.K. Gopinathan, L Mokhuts'oane, The potential of renewable energy technologies for rural development in Lesotho, Renewable Energy, 32, (4), 2007, P609-622 http.dx.doi.org/10.1016/j.renene.2006.02.014

[10] Arvind Chel, G.N. Tiwari, Stand-alone photovoltaic (PV) integrated with earth to air heat exchanger (EAHE) for space heating/cooling of adobe house in New Delhi (India), Energy Conversion \& Management, 51, (3), 2010 , 393-409. http.dx.doi.org/10.1016/j.enconman.2009.10.001

[11] Mathias Gustavsson, Anders Ellegård, The impact of solar home systems on rural livelihoods. Experiences from the Nyimba Energy Service Company in Zambia, Renewable Energy, Volume 29, Issue 7, 2004, 10591072. http.dx.doi.org/10.1016/j.renene.2003.11.011

[12] Pushpendra K. Jain, Nikolai Nijegorodov, C.G. Kartha, Role of solar energy in development in Botswana, Renewable Energy, Volume 4, Issue 2, March 1994, Pages 179-188.

[13] M.E.El-Swify and M.Z.Metias." Performance of Double Exposure Solar Still."Renewable Energy., vol.26,pp.53147(2002) http.dx.doi.org/10.1016/50960-1481(01)00160-4

[14] M.E.EL-Swify, W.H.Tadros, E.A.EL-Salam and M.Z.Metias"Long-term Experimental Evaluation of Modified L-type Solar stills." ; Journal of The Institution of Engineers ( INDIA)., vol.83,pp.21-28(2002)

[15] Litter, M.A ,Meichtry, J. M., Lin, H. J., de la Fuente, L., Levy, I. K., Gautier, E. A., Blesa, M. A. (2005), Lowcost $\mathrm{TiO} 2$ photocatalytic technology for water potabilization in plastic bottles for isolated regions. http://www.cnea.gov.ar/xxi/ambiental/aguapura/publicac iones/sol-05-1097.pdf

[16] Helwa,N.H and El-Swify, M.E, Performance of Portable Family Size Solar Box Cooker, Journal of the Institution of Engineers (INDIA), Vol.74, pp1-4, Sep.1993.

[17] El-Swify, M.E. and.Tadros, W.H, Enhancement of Energy Input to Solar Booster Cooker. Proceeding of 4th International Conference on Energy, Development \& Environment, Cairo, Egypt, 91-108, 1994

[18] ARTI Africa and its commercial partner, Joint Environmental Techniques (JET) \& H. Farag private sector 